\title{
The Possible Protective Role of Methionine against Sodium Fluoride-Induced Pancreatic Changes in the Adult Male Albino Rat: A Histological, Immunohistochemical and Morphometric Study
} Original Article

\author{
Dorreia Abd-Alla Mohammed Zaghloul, ${ }^{1}$ Wail M. Gad-El-Rab', \\ Reneah R. Bushra ${ }^{1}$, Ali Ahmed Abu-Raya Farahat ${ }^{2}$ \\ Department of Human Anatomy and Embryology, Faculty of Medicine, 'Assiut University, \\ ${ }^{2}$ Al-Azhar University
}

\begin{abstract}
Background: Excess fluorides intake produces histopathological changes of many organs. Methionine is a potential natural antioxidant against oxidative radicals.

Aim of the Work: To evaluate the possible protective role of methionine against sodium fluoride (NaF)-induced pancreatic toxicity.

Material and Methods: Thirty 3-months (200-250gm) adult male albino rats were divided into three equal groups: group I (control), group II (Fluoride group) and group III (Fluoride+methionine group). Control group; was given $1 \mathrm{ml}$ distilled water. Fluoride group; was given $10 \mathrm{mg} \mathrm{NaF} / \mathrm{kg}$ b.w. Fluoride+methionine group; was given $10 \mathrm{mg} \mathrm{NaF} / \mathrm{kg}$ b.w. and $2 \mathrm{mg}$ methionine/rat. All the treatment was given orally by gastric tube once daily for 35 days. After anesthesia, all groups were sacrificed. The pancreatic specimens were prepared for light and electron microscopic studies and anti-insulin antibody immunohistochemical staining. The mean numbers of zymogen granules and insulin positive $\beta$-cells of all groups were counted.

Results: The mean numbers of zymogen granules and insulin positive $\beta$-cells of the fluoride group were significantly decreased when compared to control. The pancreatic specimens of the fluoride group revealed congested blood vessels, extravasated blood cells, vacuolated pancreatic acini, loss of the acinar cell architecture, dilated rough endoplasmic reticulum and degenerated mitochondria. By anti-insulin antibodies immunohistochemistry, there was a weak positive reactivity in the fluoride treated group when compared to control. The concomitant administration of $\mathrm{NaF}$ and methionine improved these changes.

Conclusion: The concurrent administration of $\mathrm{NaF}$ and methionine ameliorates the structural alterations developed in the pancreas following excess $\mathrm{NaF}$ intake.
\end{abstract}

Received: 13 Novemeber 2018, Accepted: 16 January 2019

Key Words: Albino rat, methionine, pancreas, sodium fluoride.

Corresponding Author: Reneah Refaat Bushra, MD, Department of Human Anatomy and Embryology, Faculty of Medicine, Assiut University, Assiut, Egypt, Tel.: +20 1207949154, E-mail: reneah@aun.edu.eg

ISSN: 1110-0559, Vol. 42, No. 2

\section{INTRODUCTION}

The pancreas is an important digestive gland that performs a range of both endocrine and exocrine functions ${ }^{[1]}$.

Fluoride -the ionic form of fluorine- is widely spread in nature. Fluoride combines reversibly with hydrogen to form hydrogen fluoride (HF). Much of the physiological behavior of fluoride (for example, its absorption, distribution and renal clearance) is due to the diffusion of $\mathrm{HF}^{[2]}$. The ingestion of fluoride during the pre-eruptive development of the teeth has a cariostatic effect due to the uptake of fluoride by enamel crystallites and formation of fluor-hydroxy-apatite, which is less acid soluble than hydroxyapatite ${ }^{[3,4]}$.
Panget et al. ${ }^{[5]}$ reported that the total fluid intake is about $970 \mathrm{ml} /$ day. They added that the juice, tea and other beverages account for more than 50 percent of fluid intake and are rich in fluoride. Moreover, fluoride concentration ranged from $0.007-4.13 \mu \mathrm{g}$ fluoride/g food. ${ }^{[6]}$. It also enters the body through burning coal, fluoride dust and fumes from industries using fluoride containing salt and hydrofluoric acid. The blood fluoride levels of 95 parts per million (ppm) produce an increase in glucose and a decrease in insulin level ${ }^{[7}$ and 8$]$.

The elimination of absorbed fluoride occurs almost exclusively via the kidneys. The renal handling of fluoride is characterized by unrestricted filtration through the glomeruli followed by a variable degree of tubular reabsorption ${ }^{[9]}$. The sodium fluoride $(\mathrm{NaF})$ causes 
degeneration of the cells of the pancreatic acini and islets. Fluoride also causes inflammatory stromal infiltrations as well as congestion and hemorrhage of the pancreatic blood vessels $^{[10]}$.

Daily ingestion of about 1-2 ppm of fluoride found in artificially fluoridated water can result in melena, hematemesis, faintness, shallow breathing, stomach cramps, tremors, unusual increase in saliva, watery eyes, weakness, constipation, loss of appetite, skin rash, mouth and lips sores, and white, brown or black teeth discoloration ${ }^{[11,12]}$.

Methionine is a potential natural antioxidant belongs to the sulfuric amino acids ${ }^{[13,14]}$. Reser et al. ${ }^{[15]}$ stated that methionine ameliorated the nephrotoxic, hepatotoxic and ototoxic effects of some drugs. Moreover, it demonstrated a protective role in the course of exposure to the sodium fluoride. An administration of methionine reduces the oxidative stress status ${ }^{[16]}$.

Accordingly, the present study was aimed to evaluate methionine as a potential natural antioxidant to alleviate the toxic effects of $\mathrm{NaF}$ on the morphometric, light, and electron microscopic histological structure of pancreas, and the immunohistochemical reactivity.

\section{MATERIAL AND METHODS}

\section{Chemicals}

$\mathrm{NaF}$ was obtained from El-Gomhoria Chemicals Company in the form of white powder soluble in water; 1 gm of $\mathrm{NaF}$ was dissolved in $100 \mathrm{ml}$ distilled water, so $1 \mathrm{ml}$ of $\mathrm{NaF}$ solution contained $10 \mathrm{mg}$ of $\mathrm{NaF}$. Methionine was obtained from Sigma Chemicals Company in the form of powder soluble in water, $1 \mathrm{gm}$ of methionine was dissolved as $\mathrm{NaF}$, and so $1 \mathrm{ml}$ of methionine solution contained $10 \mathrm{mg}$ of methionine.

\section{Experimental Design}

The study was performed at the Faculty of Medicine, Assiut University in 2016-2018. It included thirty -3 months- adult male albino rats weighing 200-250 gm. The rats were obtained from the animal house of Assiut University. They received standard food and water during the experiment. Ethical clearance for the use of animals was got from the Institutional Animal Ethics Committee prior to the beginning of the work.

The rats were divided into three equal groups, each group contained 10 rats:

Group I (Control group): rats were given $1 \mathrm{ml}$ distilled water orally by gastric tube once daily for 35 days.

Group II (Fluoride treated group): rats were given 10 $\mathrm{mg} \mathrm{NaF} / \mathrm{kg}$ b.w., once daily for 35 days. The prepared dose was given orally by gastric tube. It is a sublethal dose causes flourosis ${ }^{[14,17]}$.

Group III (Fluoride+methionine treated group): it was given $10 \mathrm{mg} \mathrm{NaF} / \mathrm{kg}$ b.w. orally by gastric tube once daily in addition to $2 \mathrm{mg}$ methionine/rat/day orally by gastric tube for 35 days $^{[14,18,19]}$.

At the destined time, the rats of all groups were anesthetized by ether. The pancreas was extracted by opening the anterior abdominal wall. Pancreatic specimens were fixed in $10 \%$ neutral buffered formaldehyde in order to be processed for light microscopic study. Paraffin sections of $5 \mu \mathrm{m}$ thickness were stained with Haematoxylin and $\operatorname{Eosin}^{[20]}$. For electron microscopic examination, other pancreatic tissue specimens were immediately fixed in 2.5 $\%$ phosphate buffered glutaraldhyde at $4^{\circ} \mathrm{C}$ for 24 hours and post fixed in $1 \%$ osmium tetra-oxide for $1 \mathrm{~h}$. Then, they were dehydrated in ascending grades of ethanol. After immersion in propylene oxide, the specimens were embedded in epoxy resin mixture. Semithin sections of $1 \mu \mathrm{m}$ thickness were stained with toluidine blue and examined by a light microscope. Ultrathin sections of 80-90nm thickness were stained with uranyl acetate and lead citrate $^{[21]}$ and were examined using "Jeol-JEM-100 CX II" electron microscope and photographed at different magnification at the electron microscopic unit of Assiut University.

\section{Immunohistochemical study of the pancreatic islets}

Other specimens of all animal groups were prepared for immunohistochemical study under the same conditions with the same concentration of anti-insulin antibodies and at the same time. The immune-localization technique was performed on pancreatic sections of 5um thickness stained with the streptavidin-biotin-peroxidase staining method $^{[22]}$. Paraffin sections were de-paraffinized in xylene, rehydrated in alcohol of descending grades and treated with $0.3 \% \mathrm{H}_{2} \mathrm{O}_{2}$ for 20 minutes, $5 \%$ normal bovine serum (1:5 diluted TRIS) for 20 minutes and phosphate buffered saline and $10 \%$ normal goat serum for 30 minutes at room temperature to suppress the endogenous peroxidase and the non-specific antibodies binding sites. Then, the sections were incubated with anti-sera containing polyclonal primary antibodies for rat insulin (Bio-Genex, cas no.: AR.295-R.) for 1 hour. The sections were incubated with Dako-K0690; Dako Universal LSAB Kit (bio-tinylated secondary antibody) and Dako-K0690 (streptavidin horseradish peroxidase) for 30 minutes. Then, they were incubated with 3,30-diaminobenzidine 4-hydrochloride (Sigma-D5905; Sigma Aldrich Company Ltd., Gillingham, UK.) substrate kit for 10 minutes to obtain the immunelabeling. Finally, the nuclei were stained with Harry's Haematoxylin stain, dehydrated in graded alcohol, cleared in xylene and mounted in DPX. A light microscope was used to examine the antibodies binding ${ }^{[23]}$.

\section{Morphometric study}

Using computerized assisted image analysis, the zymogen granules of all animal groups were counted per area of $2604987 \mu \mathrm{m} 2$ via electron microscopic micrographs of pancreatic specimens of $x 3600$. The number of insulin positive $\beta$-cells of all animal groups was also counted per area of $86506 \mu \mathrm{m} 2$ via light microscopic examination of 
the anti-insulin antibodies immune-stained photographs of $\mathrm{x} 400$.

\section{Statistical analysis}

The morphometric results were expressed as means \pm standard deviation (SD). Multiple comparisons testing were done using ANOVA and the post-hoc test (LCD) for pair wise comparison. Values of $p \leq 0.05$ were considered statistically significant. All analyses were carried out with SPSS version 21.0 (SPSS Inc., Chicago, USA).

\section{RESULTS}

\section{Morphometric results}

The fluoride group rats (group II) showed a significant decrease of the mean number of zymogen granules per area of $2604987 \mu \mathrm{m} 2(97.60 \pm 3.80)$ as compared with the control group (137.40 \pm 5.27$)$. The present data revealed that a concomitant administration of methionine with fluoride (group III) caused a significant increase in the mean number of zymogen granules (134.20 \pm 3.64$)$ as compared with the fluoride group (Table 1, Graph 1).

The fluoride group rats (group II) showed a significant decrease of the mean number of the insulin positive $\beta$-cells per area of $86506 \mu \mathrm{m} 2(48.50 \pm 3.02)$ as compared with the control group (113.80 \pm 2.65$)$. The concomitant administration of methionine with fluoride (group III) caused a significant increase in the mean number of the insulin positive $\beta$-cells $(112.40 \pm 1.57)$ as compared with the fluoride group (Table 2, Graph 2).

\section{Light microscopic results}

Light microscopic examination of the control rat pancreatic sections revealed a presence of thin connective tissue septa dividing the organ into lobules of variable sizes and shapes. Within the lobules, rounded or oval serous acini represented the exocrine portion of the pancreas. The endocrine part (the islets of Langerhans) was observed among the exocrine part. The pancreatic acini appeared rounded or oval in shape. They were lined with pyramidal cells arranged around a narrow acinar lumen. The acinar cells contained basal rounded nuclei. Some cells had double nuclei. The supranuclear portions of the cells were packed with acidophilic zymogen granules, while the basal portions of the cells had basophilic cytoplasm. The islets of Langerhans appeared pale pink oval or rounded areas inside the pancreatic lobules and formed of circular groups of cells (Figures 1-3).

The light microscopic examination of the rat pancreas of group II revealed dilatation and congestion of the blood vessels. Extravasation of blood cells into the interlobular connective tissue, loss of the normal acinar architecture and appearance of many cytoplasmic vacuoles were observed (Figs. 4-7).
The light microscopic examination of the rat pancreas of group III revealed regression of the previously mentioned histological findings in group II. Apart from residual vacuoles, the lobular architecture was preserved and the acini were more regular with apical acidophilic zymogen granules (Figs. 8 and 9).

\section{Electron microscopic results}

By electron microscopy, the pancreatic acinar cells of the rat pancreas of the control group were pyramidal in shape. They contained basal and rounded nuclei surrounded by mitochondria. The apical part of the cytoplasm contained rounded, electron-dense and smooth membranebounded zymogen granules of variable size. The cells were mostly filled with the rough endoplasmic reticulum (rER) (Figures 10 and 11).

Electron microscopic examination of the pancreatic acinar cells of group II revealed shrunken nuclei and dilated rER. Vacuolated and balloon-shaped mitochondria with ill-defined cristae were noticed. There were cytoplasmic vacuoles, autophagosomes and scanty zymogen granules (Figures 12-15).

Electron microscopic examination of the rat pancreas of group III showed normal acinar cells except for residual dilated rER and swollen mitochondria (Figures 16-18).

\section{Immunohistochemical results}

Anti-insulin antibody immunohistochemically revealed that, the $\beta$-cells of the control rat group were stained with strong positive reaction for anti-insulin antibodies in the form of brown granules (Figure 19). $\beta$-cells of the pancreas of group II revealed a weak reaction (Figure 20). $\beta$-cells of the rat pancreas of group III were stained with strong positive reaction for anti-insulin antibodies more similar to control (Figure 21).

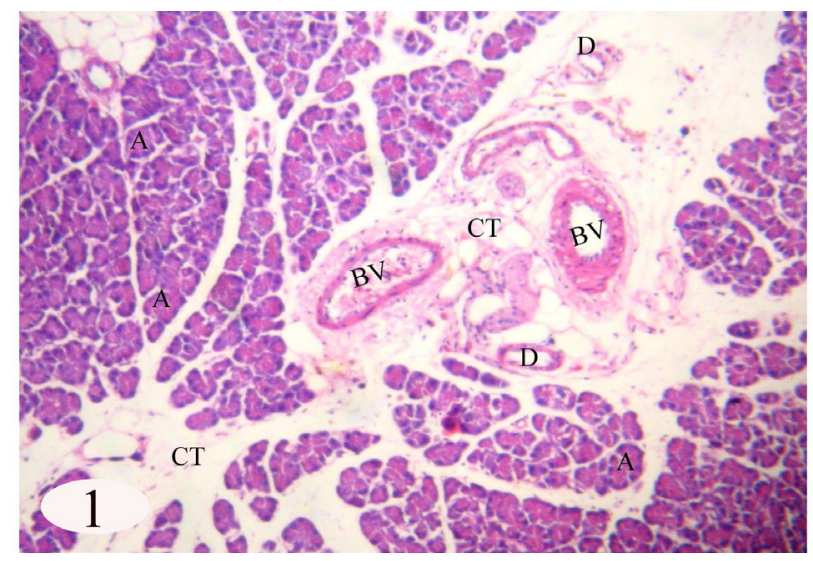

Fig. 1: A photomicrograph of a longitudinal section of an adult control rat pancreas (group I) showing closely packed pancreatic lobules with acini of different sizes and shapes (A) separated by interlobular connective tissue (CT) containing pancreatic ducts (D) and inter-lobular blood vessels (BV). 


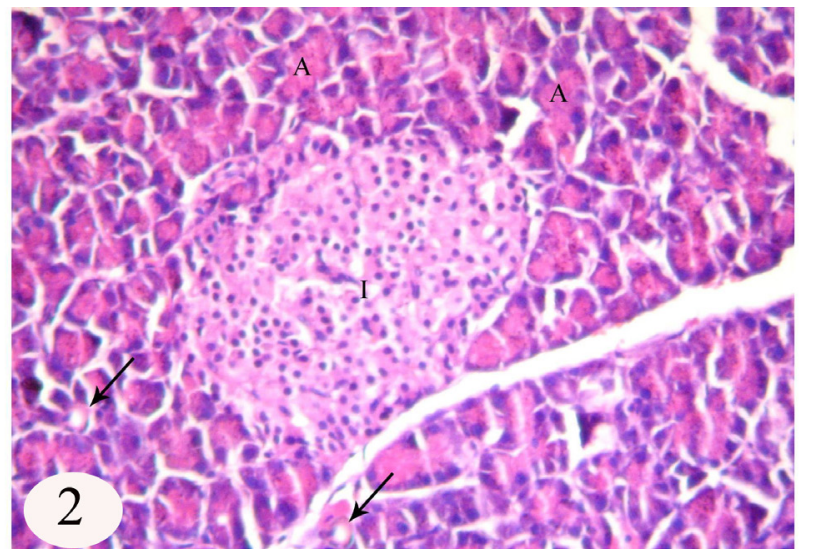

Fig. 2: A photomicrograph of a longitudinal section of an adult control rat pancreas (group I) showing an islet of Langerhans (I) appearing as a pale oval area among dark acini (A). Notice the intra-lobular ducts (arrow) lined by flat cells.

(H\&E; x 100)

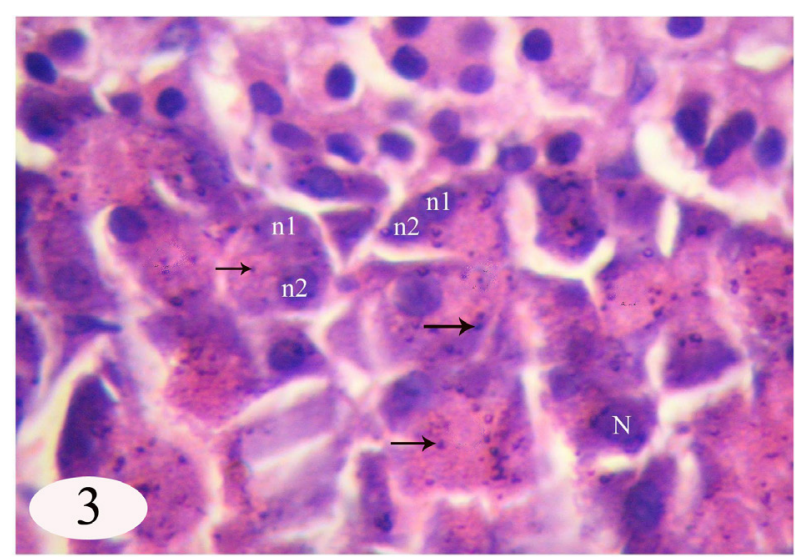

Fig 3: A photomicrograph of a longitudinal section of an adult contro rat pancreas (group I) showing the pyramidal pancreatic acinar cells with a peripheral darkly-stained nucleus $(\mathrm{N})$. Some cells have double nuclei (nl) and (n2). Notice the apical part of the acinar cell contains zymogen granules (arrow).

(H\&E; x 400)

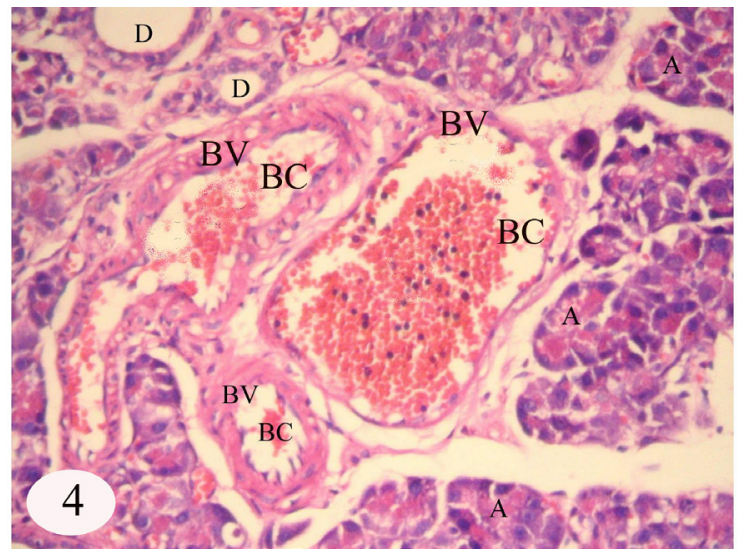

Fig. 4: A photomicrograph of a longitudinal section of an adult fluoridetreated rat pancreas (group II) showing dilated and congested blood vessels $(\mathrm{BV})$ with blood cells $(\mathrm{BC})$ inside them. Notice the pancreatic acini (A) and interlobular ducts (D).
(H\&E; x 100)

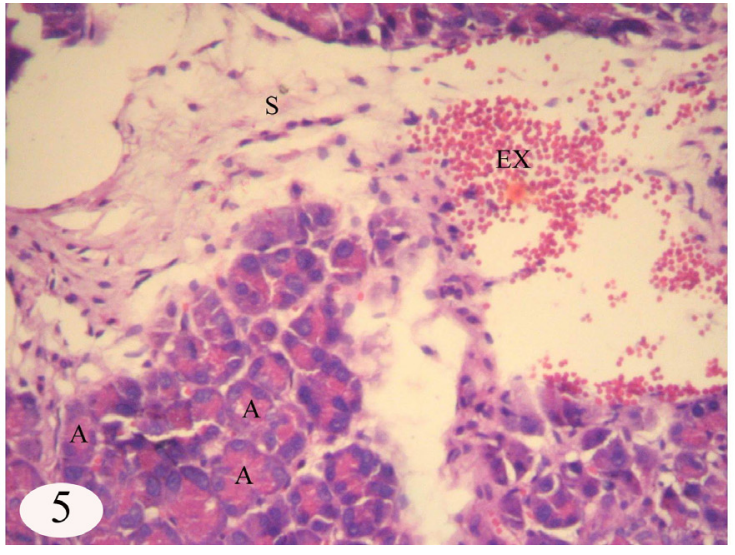

Fig. 5: A photomicrograph of a longitudinal section of an adult fluoridetreated rat pancreas (group II) showing extravasated blood (EX) into the interlobular spaces (S). Notice the intact pancreatic acini (A). (H\&E; x 100)

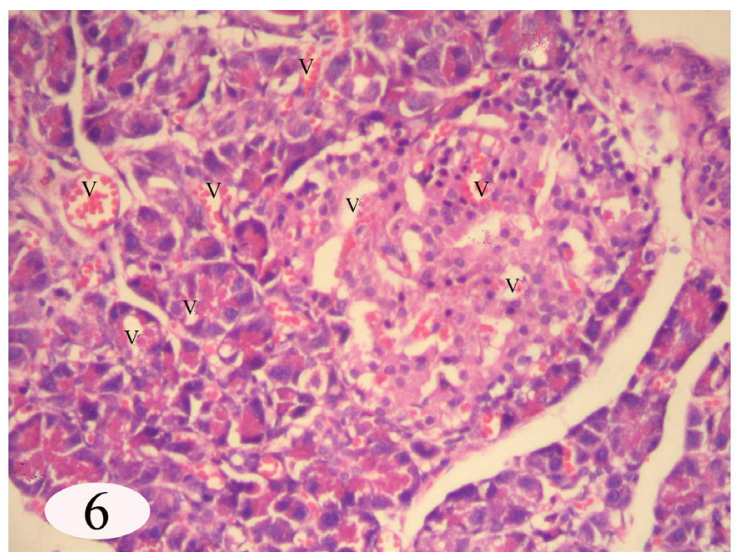

Fig. 6: A photomicrograph of a longitudinal section of an adult fluoride-treated rat pancreas (group II) showing dilated blood vessels (V) among the pancreatic acinar cells and the islets of Langerhans. (H\&E; x100)

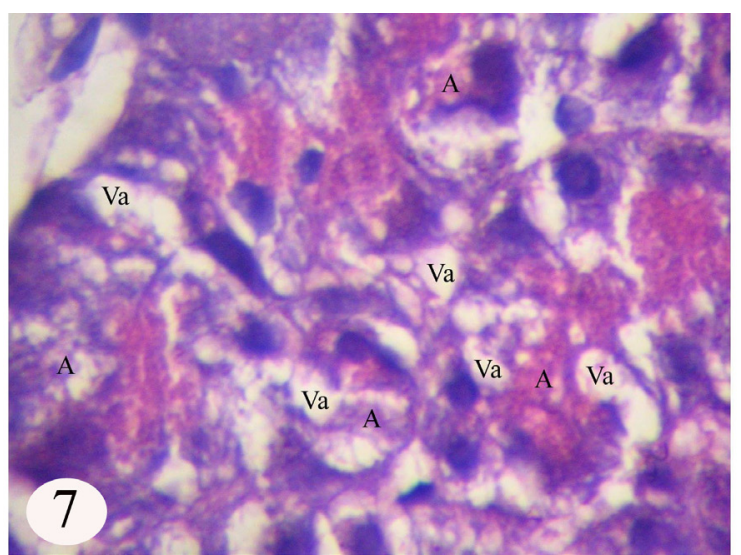

Fig. 7: A photomicrograph of a longitudinal section of an adult fluoridetreated rat pancreas (group II) showing complete loss of normal architecture of pancreatic acini (A). Notice the multiple cytoplasmic vacuoles of variable sizes (Va) in the cytoplasm of the acinar cells (A). (H\&E; x 400) 


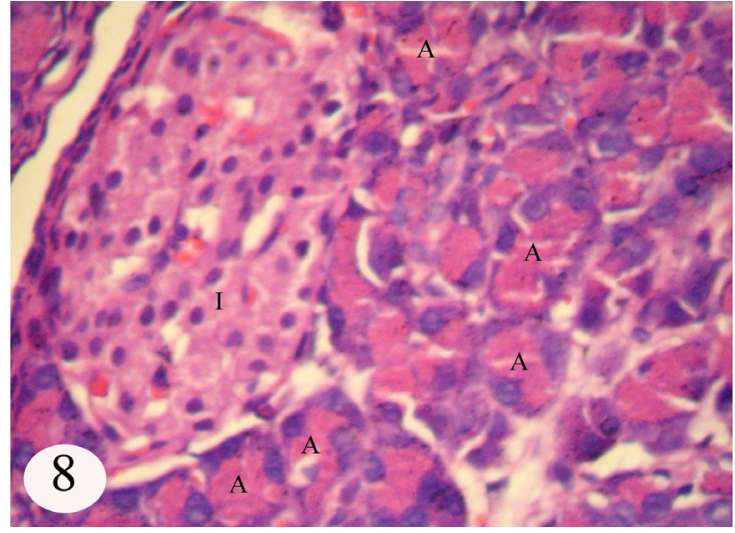

Fig. 8: A photomicrograph of a longitudinal section of an adult fluoride+methionine-treated rat pancreas (group III) showing wellorganized pancreatic acini (A) and an islet of Langerhans (I) more similar to control.

(H\&E; x 200)

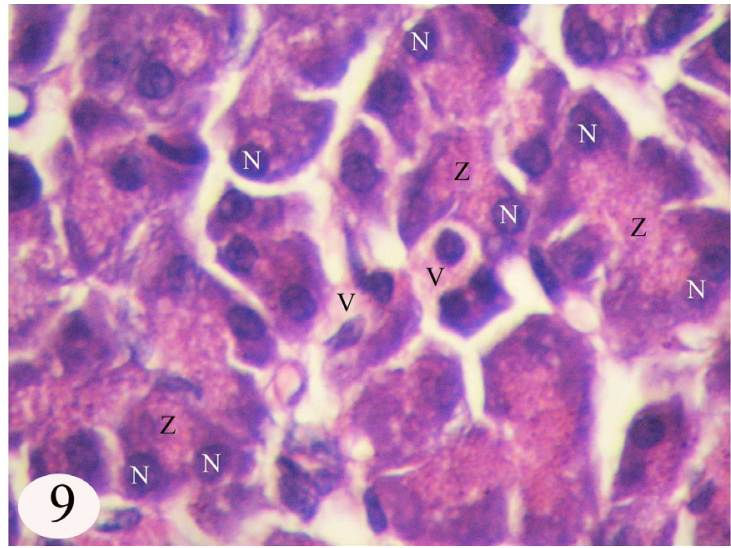

Fig. 9: A photomicrograph of a longitudinal section of an adult fluoride+methionine-treated rat pancreas (group III) showing normal architecture of pancreatic acini with nuclei $(\mathrm{N})$ and apical zymogen granules (Z). Notice residual vacuoles (V).

(H\&E; x 400)

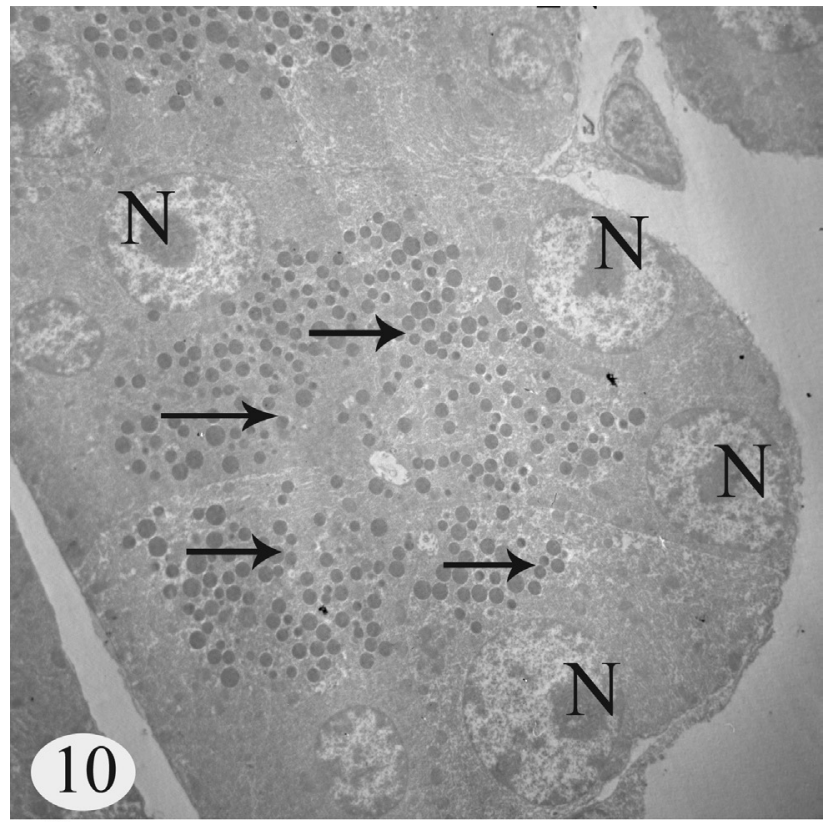

Fig. 10: An electron-micrograph of an adult control rat pancreas (group I) showing acinar cells with euchromatic nuclei $(\mathrm{N})$ and numerous electron dense secretory granules of variable sizes (arrow) in the apical part.x 1900

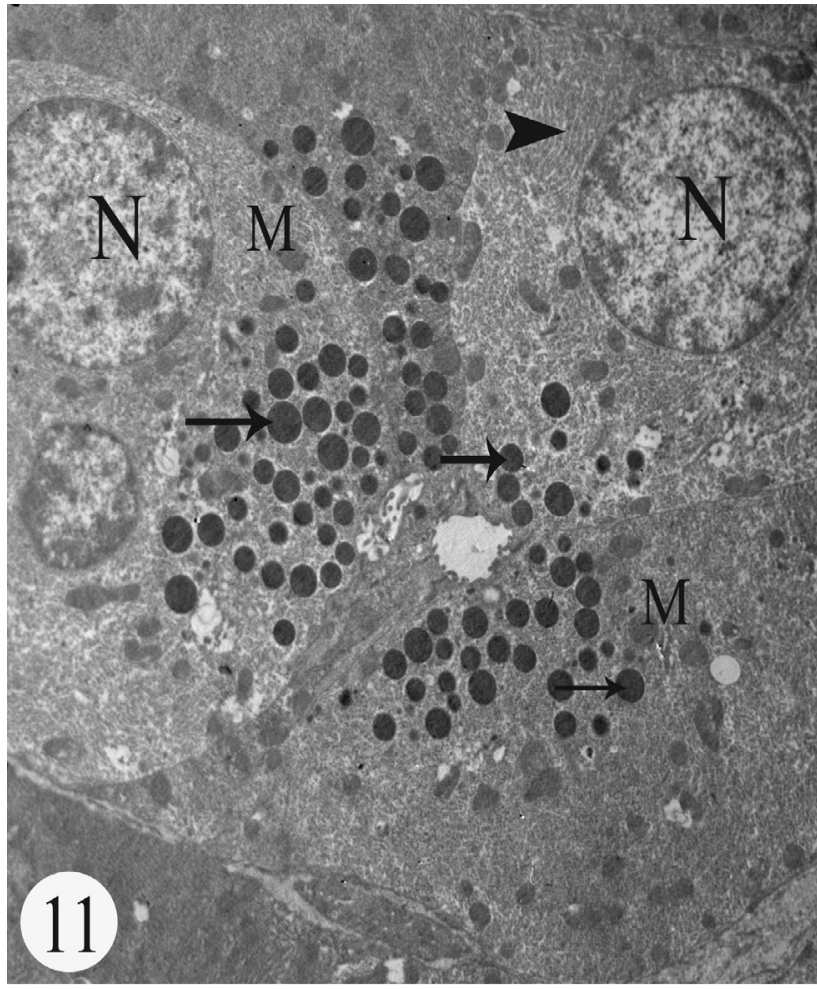

Fig. 11: An electron-micrograph of an adult control rat pancreas (group I) showing acinar cells with euchromatic nuclei $(\mathrm{N})$, welldeveloped cisternae of rER (arr owhead), mitochondria (M) and numerous electron dense secretory granules of variable sizes (arrow). $\quad$ x 3600

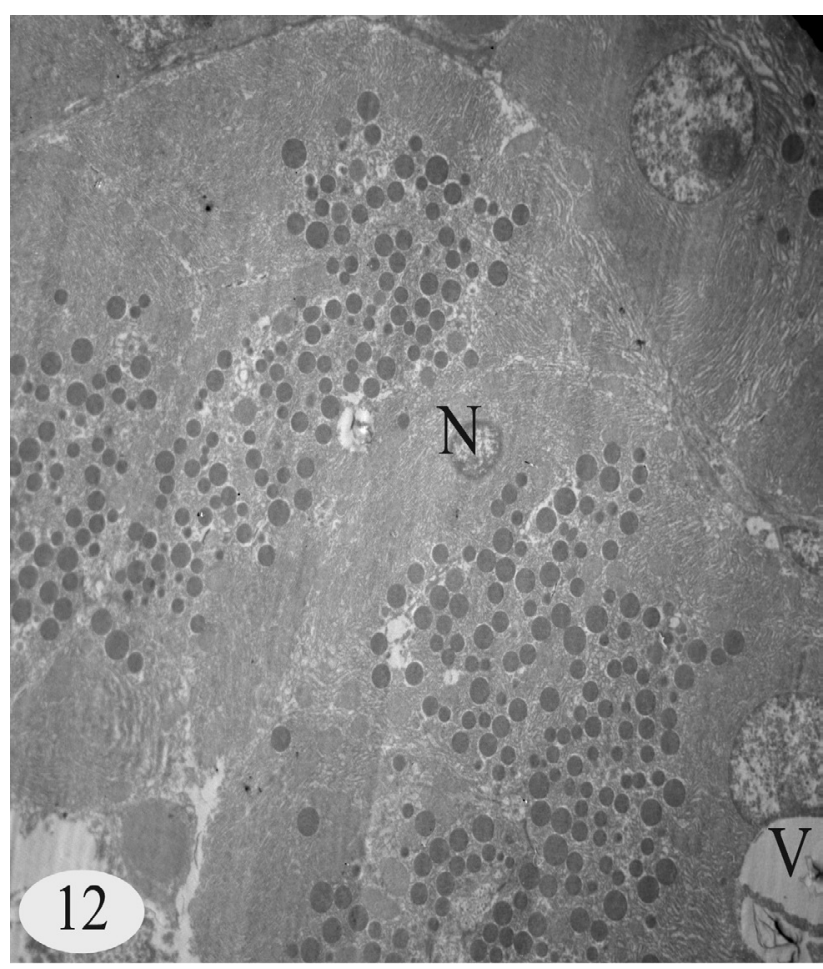

Fig. 12: An electron-micrograph of an adult fluoride-treated rat pancreas (group II) showing shrunken pancreatic acinar nuclei $(\mathrm{N})$ and vacuoles (V).

x 1900 


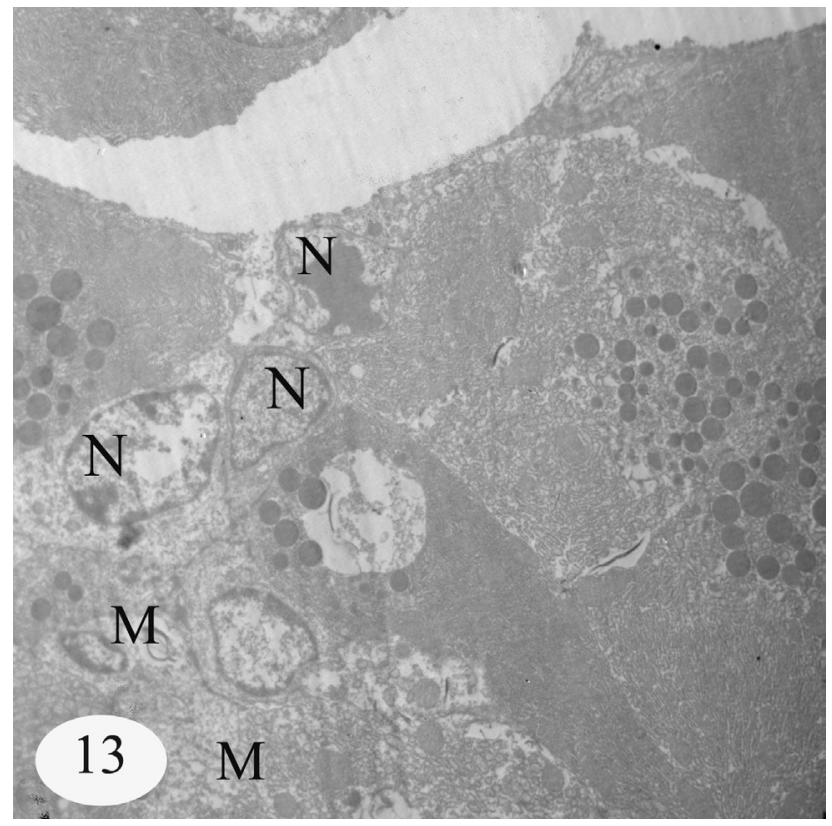

Fig. 13: An electron-micrograph of an adult fluoride-treated rat pancreas (group II) showing irregular pancreatic acinar nuclei $(\mathrm{N})$ and damaged mitochondria $(\mathrm{M})$.

x 2900

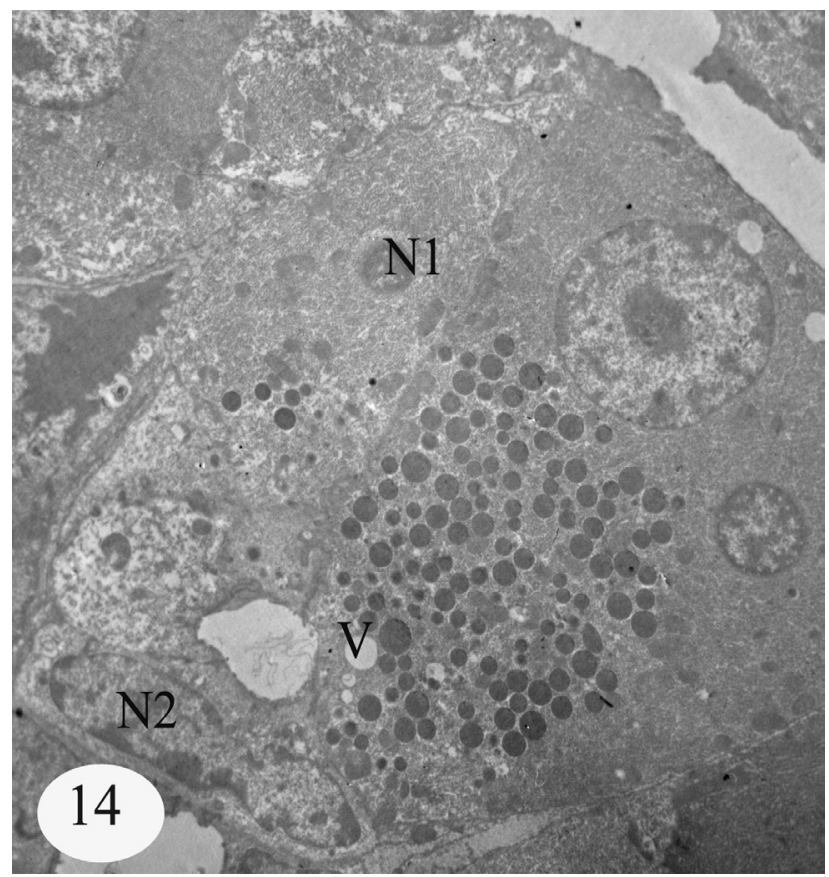

Fig. 14: An electron-micrograph of an adult fluoride-treated rat pancreas (group II) showing a pyknotic irregular nucleus (N1), an irregular nucleus (N2) and cytoplasmic vacuolation (V).

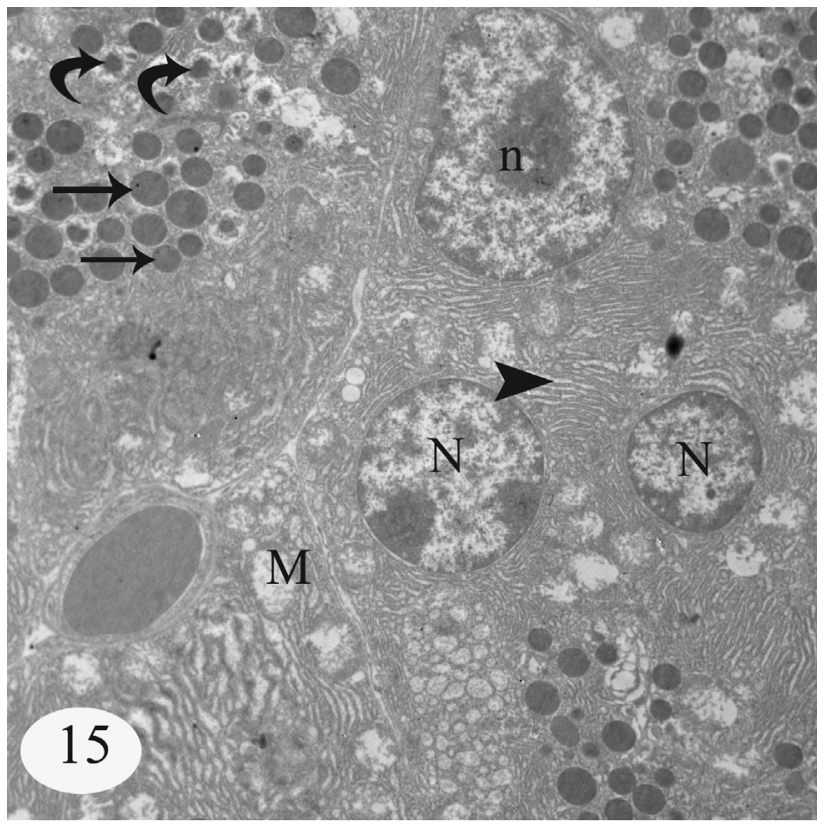

Fig. 15: An electron-micrograph of an adult fluoride-treated rat pancreatic acinar cells (group II) showing a hyperchromatic nucleus $(\mathrm{N})$, a nucleus with a large central nucleolus (n), dilated rER (arrowhead), balloon-shaped mitochondria (M) and phagosomes (curved arrow). Notice secretory granules (arrow) of variable sizes in the apical part.

x 3600

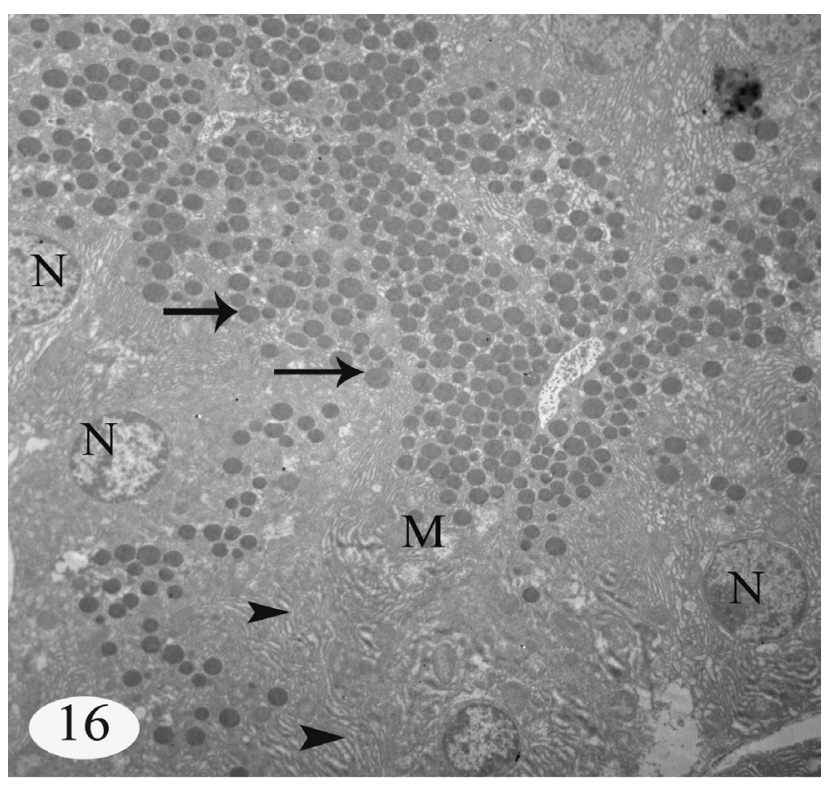

Fig. 16: An electron-micrograph of an adult fluoride+methionine-treated rat pancreas (group III) showing acinar cells nuclei $(\mathrm{N})$ with architecture more similar to control, numerous secretory granules $(\mathrm{Z})$, residual dilated rER (arrow) and balloon-shaped mitochondria (M).

x 1900 


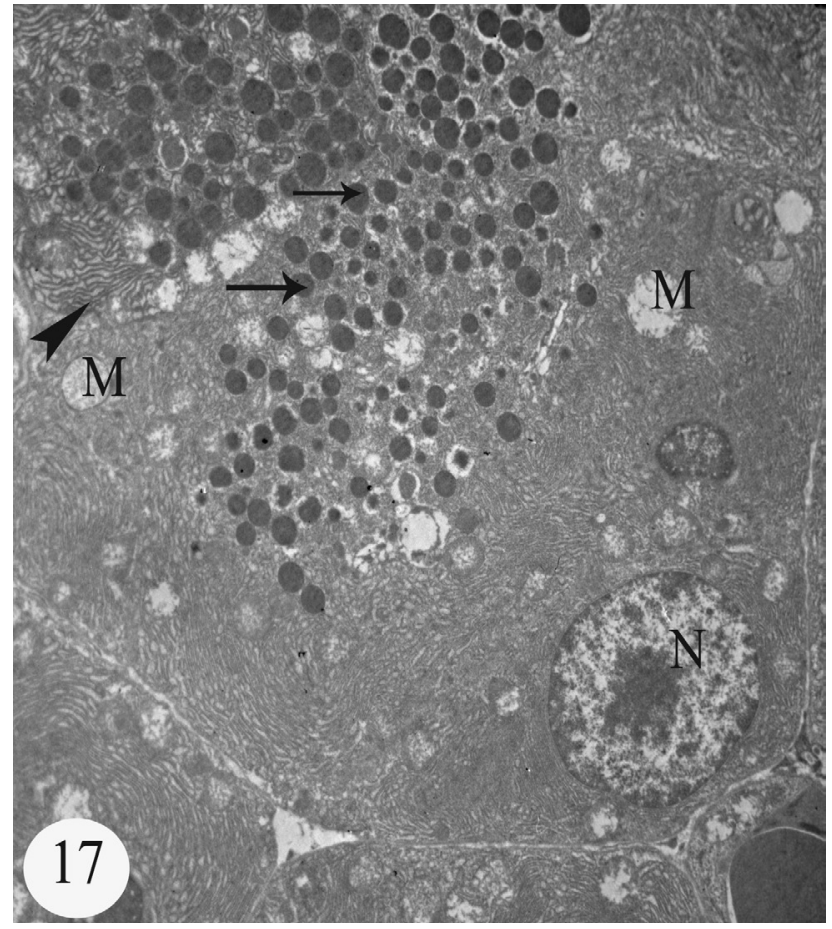

Fig. 17: An electron-micrograph of an adult fluoride+methionine-treated rat pancreas treated (group III) showing acinar cells with a nucleus $(\mathrm{N})$, rER (arrowhead), numerous cytoplasmic secretory granules (arrow). Balloon-shaped mitochondria with lost cisternae (M) are still seen. x 2900

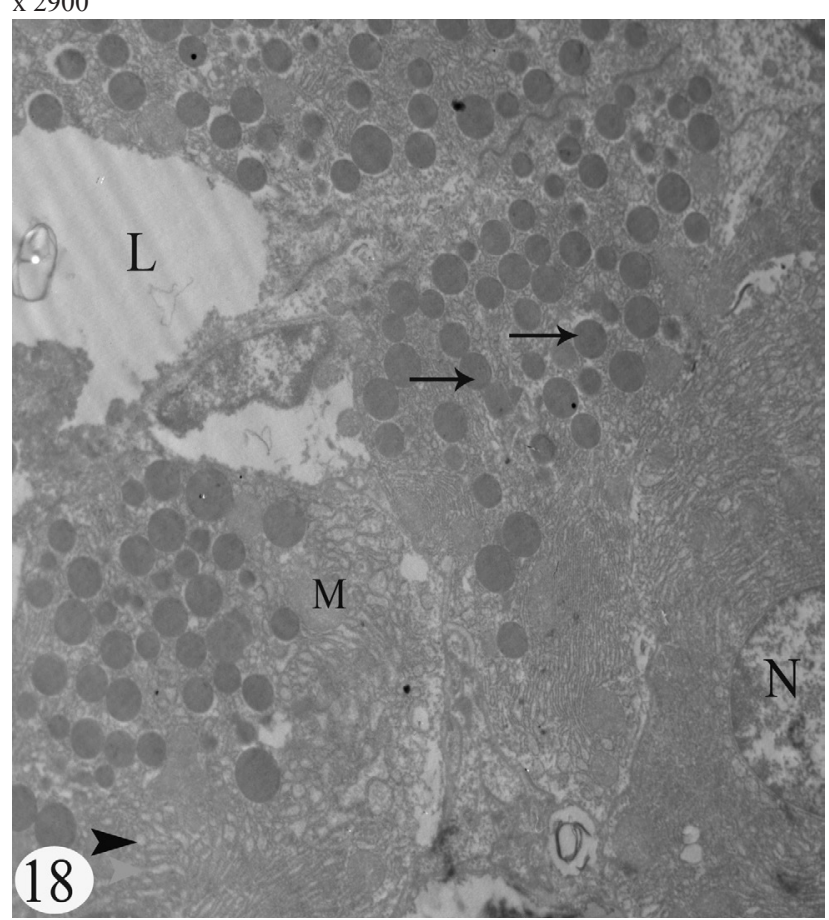

Fig. 18: An electron-micrograph of an adult fluoride+methionine-treated rat pancreas (group III) showing acinar cells with an euchromatic nucleus (N), dilated rER (arrowhead), looking like normal mitochondria (M) and numerous secretory granules (arrow). Notice the acinar lumen (L). x 3600

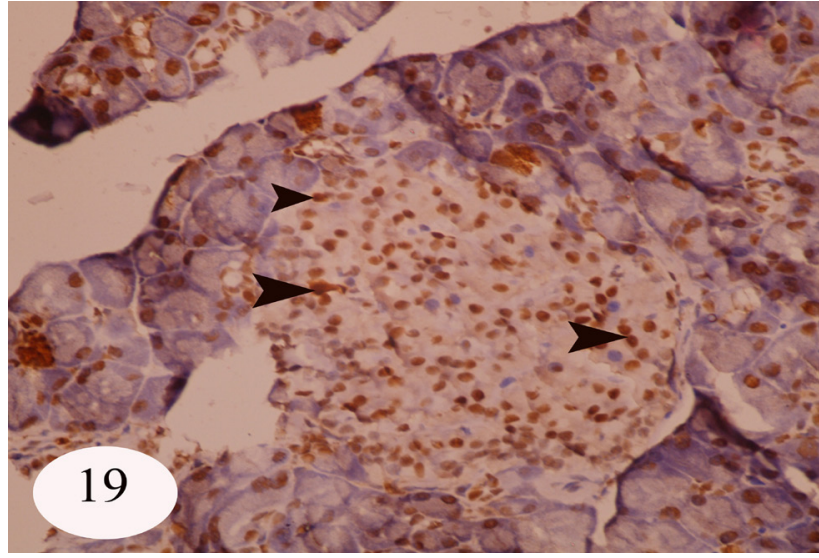

Fig. 19: An anti-insulin immune-reactivity photomicrograph of an adult control rat pancreatic islet (group I) showing brown-stained pancreatic $\beta$-cells with strong positive immune-reaction (arrowhead) x 400

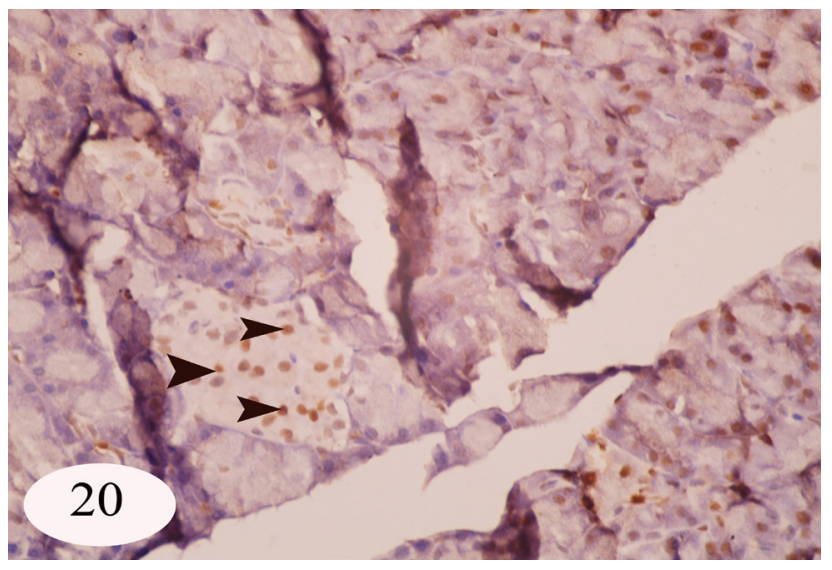

Fig. 20: An anti-insulin immune-reactivity photomicrograph of an adult fluoride-treated rat pancreatic islet (group II) showing pancreatic $\beta$-cells with weak positive immune-reaction (arrowhead). $\mathrm{x} 400$

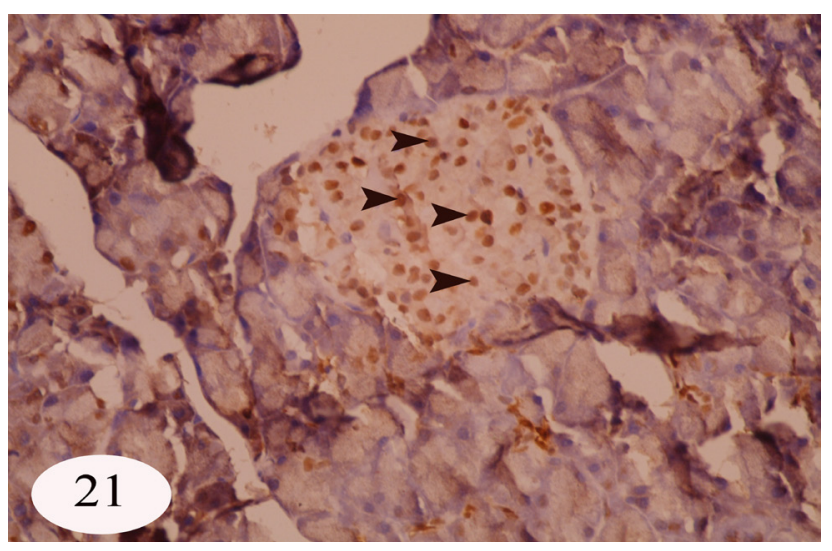

Fig. 21: An anti-insulin immune-reactivity photomicrograph of an adult fluoride+methionine-treated rat pancreatic islet (group III) showing pancreatic $\beta$-cells with strong positive immune-reaction similar to the control (arrowhead).

$\mathrm{x} 400$ 
Table 1: The number of pancreatic zymogen granules per area of $2604987 \mu \mathrm{m} 2$ of the different studied animal groups.

\begin{tabular}{lccc}
\hline & $\begin{array}{c}\text { Control Group } \\
\text { (Group I, } \mathrm{n}=10) \\
\text { Mean+SD }\end{array}$ & $\begin{array}{c}\text { Fluoride-treated (Group II, } \mathrm{n}=10) \\
\text { Mean+SD }\end{array}$ & $\begin{array}{c}\text { Fluoride plus methionine } \\
(\text { Group III, } \mathrm{n}=10) \\
\text { Mean+SD }\end{array}$ \\
\hline Zymogen granules number & $137.40 \pm 5.27$ & $97.60 \pm 3.80^{\mathrm{a}}$ & $134.20 \pm 3.64^{\mathrm{b}}$ \\
\hline
\end{tabular}

a Significant when compared with the control group; $p \leq 0.05$

b Significant when compared with the Fluoride-treated group; $p \leq 0.05$

Table 2: The number of insulin positive $\beta$-cells per area of $86506 \mu \mathrm{m} 2$ of all animal groups.

\begin{tabular}{lccc}
\hline & $\begin{array}{c}\text { Control Group } \\
\text { Group I, } \mathrm{n}=10) \\
\text { Mean+SD }\end{array}$ & $\begin{array}{c}\text { Fluoride-treated (Group II, n=10) } \\
\text { Mean+SD }\end{array}$ & $\begin{array}{c}\text { Fluoride plus methionine } \\
(\text { Group III, } \mathrm{n}=10) \\
\text { Mean+SD }\end{array}$ \\
\hline Insulin positive $\beta$ cells number & $113.80 \pm 2.65$ & $48.50 \pm 3.02^{\mathrm{a}}$ & $112.40 \pm 1.57^{\mathrm{b}}$ \\
\hline
\end{tabular}

a Significant when compared with the control group; $p \leq 0.05$

b Significant when compared with the Fluoride-treated group; $p \leq 0.05$

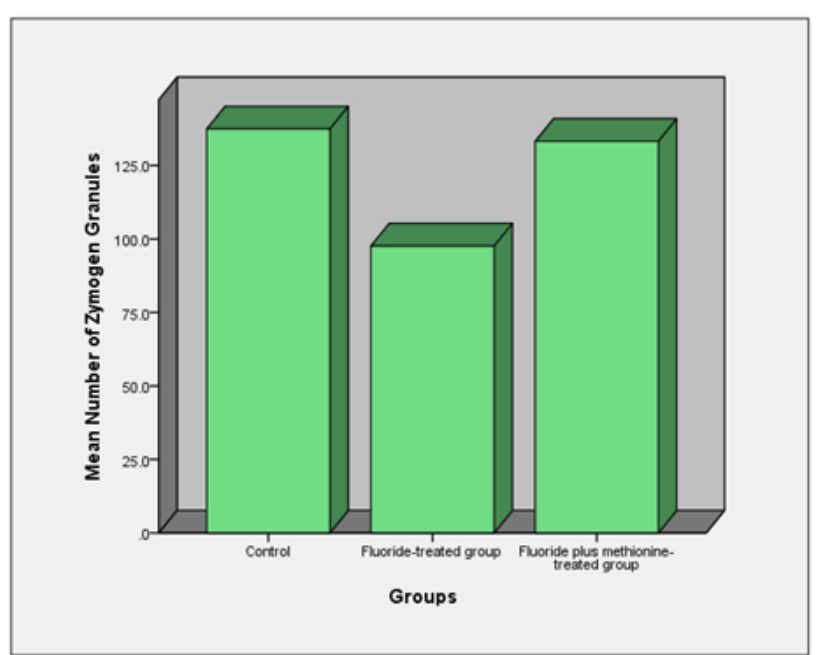

Graph 1: showing the number of the pancreatic zymogen granules per area of $2604987 \mu \mathrm{m} 2$ of the different studied groups.

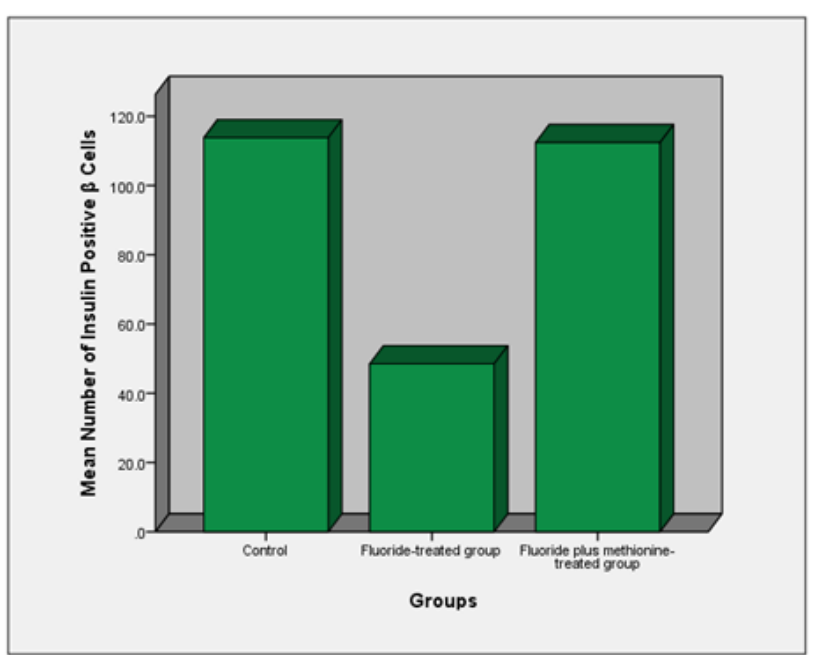

Graph 2: showing the number of insulin positive $\beta$-cells per area of $86506 \mu \mathrm{m} 2$ of all animal groups.

\section{DISCUSSION}

Fluoride is the most potent and effective substance for prevention and treatment of dental caries. Sodium fluoride is used as an antihelmintic, disinfectant and anticoagulant. Through the $20^{\text {th }}$ century, fluoride attracted an interest due to its deleterious effects at high concentrations in human populations and experimental models ${ }^{[24,25]}$. Fluoride in amounts exceeding the standard therapeutic dosage accumulates in the hard and soft tissues where it produces significant changes in many organs, including liver, kidney, lung, endocrine glands, pancreas, reproductive and nervous systems ${ }^{[20]}$.

The histological examination of the exocrine portion of pancreas of fluoridated rats of the current study exhibited structural alternations. The most prominent alternation was the occurrence of multiple vacuoles in the cytoplasm of the pancreatic acini. This finding was in consistence with the histological findings of many investigators who reported the occurrence of vacuolar degeneration in the pancreas of $\mathrm{NaF}$ treated animals ${ }^{[13,17,18,25]}$. The fluoride toxicity leads to loss of the selective permeability of the cell membrane, resulting in dilatation of the cytoplasmic components secondary to intracellular fluid and electrolyte redistribution ${ }^{[25,26,27,28]}$.

In the current study, NaF produced dilatation and congestion of the pancreatic blood vessels and extravasations of blood cells into the interstitial spaces between the pancreatic lobules. These findings are similar to the results of Sharma et al. ${ }^{[11]}$ and Guney et al. ${ }^{[29]}$ who found congestion of blood vessels and infiltration of the blood cells in the surrounding area.

The current electron microscopic examination of the pancreatic acinar cells of the fluoridated animals revealed dilatation of the rough endoplasmic reticulum (rER). Matsuo et al. ${ }^{[30]}$ reported that the rER of the cells of the NaF-treated rat was dilated, disrupted and attained 
a globular shape. They attributed that to the toxic effect of fluoride that disrupted the export of zymogens from the rER. They added that, during the secretory process, incompletely assembled and aggregated products were selectively retained in the rER. Qujeq et al. ${ }^{[31]}$ reported that fluoride inhibited protein synthesis.

The ultrastructural examinations of the NaFtreated animals' pancreas of the current study revealed mitochondrial vacuolation and balloon-shaped ones with ill-defined cristae. These findings are similar to the results of Sharma et al. ${ }^{[11]}$ who reported the most significant morphological changes observed in the tissues exposed to NaF-treated animals included damage to mitochondria. Also, the ultrastructural examinations of the NaF-treated animals' pancreas of the current study revealed that the zymogen granules were scanty. Such a finding was parallel with the morphometric result of the present work. This observation comes in agreement with the results of Agha et al. ${ }^{[14]}$ who reported reduction in the numbers of zymogen granules of the NaF-treated animals' pancreas.

Moreover, these findings indicate that the fluoride disrupts the export of the zymogen granules from the rER. The most fundamental adverse effect of fluorides is the inhibition of Kreb's cycle enzymes as reported by Hordyjewska and Pasternak ${ }^{[26]}$. Thus it affects the metabolic pathways of carbohydrates, lipids and protein ${ }^{[30]}$. It also induces formation of free radicals disturb the action of the antioxidants. That disturbance leads to an oxidative stress damages the metabolism of all compounds found in the cell and causes apoptosis ${ }^{[32,33,34]}$.

In the present study, the administration of methionine during the fluoride treatment reduced the pathological changes induced by fluoride. Few acinar cells contained vacuoles and the electron microscopic examination showed normal pancreatic acini except for some dilated cisterns of the endoplasmic reticulum and mitochondria. This agrees with Stawiarska-pieta et al ${ }^{[18]}$ who stated that an application of antioxidants leads to an increase in the protein level and a subsequent increase in the number of zymogen granules accompanied with no or mild dilatation of the rER.

The immune-reactivity for the anti-insulin antibodies of the NaF-treated rats of the present study was weak. This comes in agreement with Chalubek ${ }^{[35]}$ who elicited hyperglycemia in rats exposed to 50 or $100 \mathrm{ppm}$ fluoride in drinking water for four months. Concomitant treatment with methionine in the present work revealed positive immune-reactions of the $\beta$-cells for anti-insulin antibodies.

\section{CONCLUSION}

An increased fluoride intake plays a significant role in the pancreatic toxicity, and that an administration of antioxidants such as methionine in concomitant to fluoride may protect the pancreas against the harmful effects.

\section{CONFLICT OF INTEREST}

The authors declare that there is no conflict of interest.

\section{REFERENCES}

1. Standring S., Neel A., Girish J., Patricia C.and Alan R. and Caroline B. (2016): Gray's Anatomy, 41th Ed. Ch.; 77. Pp.:1183-1190.

2. Lockner F., Twetman S. and Stecksén-Blicks C. (2017): Urinary fluoride excretion after application of fluoride varnish and use of fluoride toothpaste in young children. Int. J. Paediatr. Dent.; 27(6): 463-468.

3. Maarafi A., Hara A., Levon J., Chu T., Eckert G. and Lippert F. (2018): The Effects of Fluoride Treatment Time and Concentration on In Vitro Caries Lesion Demineralisation and Remineralisation. Oral Health Prev. Dent.; 16(6):557-562.

4. Pollick H. (2018): The Role of Fluoride in the Prevention of Tooth Decay. Pediatr. Clin. North Am.; 65(5):923-940.

5. Panget D.T., Phillips C.L. and Bawden J.W. (1992): Fluoride intake from beverage consumption in a sample of North Carolina children. J. Dent. Res.; 71:1382-1388.

6. Steele J., Martinez-Mier E., Sanders B., Jones J., Jackson R., Soto-Rojas A., Tomlin A. and Eckert G.( 2014): Fluoride content of infant foods. Gen. Dent.; 62(2):72-74.

7. Taves, D.R. (1983): Diatary intake of fluoride ashed (total fluoride). Unashed (inorganic fluoride) analysis of individual foods. Br. J. Nutr.; 49: 295-301.

8. Menoyo I., Rigalli A. and Puche RC. (2005): Effect of fluoride on the secretion of insulin in the rat. Drug Res.; 55(5):455-460.

9. Dimcevici N., Bălălău C., Nimigean V., Nimigean V., Ion I., Baconi D., Bârcă M. and Băran V. (2014): Histopathological changes of renal tissue following sodium fluoride administration in two consecutive generations of mice. Correlation with the urinary elimination of fluoride. Rom. J. Morphol. Embryol.; 55(2):343-349.

10. Dabrowska E., Balunowska M., Letko R. and Szynaka B. (2004): Ultra structural study of the mitochondria in the submandibular gland, the pancreas and the liver of young, exposed to Naf in drinking water. A.A.M.B. 49 (Suppl.1):180-181.

11. Sharma D., Singh A., Verma K., Paliwal S., Sharma S. and Dwivedi J. (2017): Fluoride: A review of pre-clinical and clinical studies. Environ. Toxicol. Pharmacol.; 56:297-313. 
12. Warren A. and Mitchell D. (2000): Fluoride: Friend or foe? Part3. www.Alaska wellness.com. Pp.:1-8.

13. Martínez Y., Li X., Liu G., Bin P., Yan W., Más D., Valdivié M., Hu C., Ren W. and Yin Y. (2017): The role of methionine on metabolism, oxidative stress, and diseases. Amino Acids; 49(12):2091-2098.

14. Agha F.E., El-Badry M.O., Hassan M.O. and Abd Elraouf A. (2012): Role of Vitamin $\mathrm{E}$ in Combination with Methionine and Lcarnosine Against Sodium Fluoride-Induced Hematological, Biochemical, DNA Damage, Histological and Immunohistochemical Changes in Pancreas of Albino Rats. Life Science Journal; 9(2):1260-1275.

15. Reser D., Rho M., Dewan D., Herbst L., Li G., Stupak H., Zur K., Romaine J., Frenz D., Goldbloom L., Kopke R., Arezzo J. and Van DeWater T. (1999): L- and D-methionine provide long term protection against CDDP-induced ototoxicity in vivo, with partial in vitro and in vivo retention of antineoplastic activity. Neurotoxicology; 20:731-748.

16. Błaszczyk I., Grucka-Mamczar E., Kasperczyk S. and Birkner E. (2009): Influence of methionine upon the concentration of malondialdehyde in the tissue and blood of rats exposed to sodium fluoride. Biol. Trace Elem. Res.; 129:229-238.

17. Blaszczyk I., Grucka-Mamczar E., Kasperczyk S. and Birkner E., (2008): Influence of fluoride on rat kidney antioxidant system: effects of methionine and vitamin E. Biol. Trace Elem. Res.; 121:51-59.

18. Stawiarska-pieta B., Paszczela E., GrukaMamczar E., Szaflarska-Stojko and Brinker E. (2009): The effect of antioxidative vitamins A and E and Coenzyme Q on the morphological picture of the lungs and pancreata of rats intoxicated with sodium fluoride. Food and Chemical Toxicology; 47:254-250.

19. Stawiarska-Pieta B., Grucka-Mamczar E., Szaflarska-Stojko E., Birkner E. and Ziebowicz M. (2007): The influence of diet supplementation with methionine and vitamin $\mathrm{E}$ on the morphological picture of rats organs intoxicated with sodium fluoride. In: Acta Biochimicapotonica Pol.; 52(Supl. 4):137-143.

20. Bancroft J. and Steven A. (1996): Theory and practice of histological techniques. 4th ed. Churchill living stone. Edinburgh and London.

21. Bozzola J. and Russell L. (1998): Electron microscopy: Principles and techniques for biologists. Jones and Battlett Publishers, Sandbury. USA. 2nd ed.

22. Cemek M., Kag a S., Simsek N., Büyu“kokurog lu
M. and Konuk M., (2008): Antihyperglycemic and antioxidative potential of Matricaria chamomilla L. in streptozotocin-induced diabetic rats. J. Nat. Med.; 62:284-293.

23. Abdul-Hamid and M. Moustafa N. (2013): Protective effect of curcumin on histopathology and ultrastructure of pancreas in the alloxan treated rats for induction of diabetes. The Journal of Basic and Applied Zoology; 66(4):169-179.

24. Meriç G., Güvenir M. and Suer K. (2017): Effectiveness of non-fluoride and fluoride dentifrices for denture hygiene. Acta Odontol. Scand.; 75(6):437-441.

25. Barbier O., Arreola-Mendozab L. and RazoaL M.D. (2010): Molecular mechanisms of fluoride toxicity. Chemico-Biological Interactions; 188:319-333

26. Hordyjewska a. and Pasternak K. (2004): Influence of Fluoride on Organism of Human. J. Elemental.; 9 (4): 883-897.

27. Shashi A., Sharma N. and Bhardwaj M. (2010): Pathological evaluation of pancreatic exocrine glands in experimental fluorosis. Asian Pacific Journal of Tropical Medicine; 3:36-40.

28. Cicek E., Aydin G., Akdogan M. and Okutan H. (2005): Effects of chronic ingestion of sodium fluoride on myocardium in a second generation of rats. Human Experimental Toxicology; 24(2):79-87.

29. Guney M., Oral B., Demirin H., Karahan N., Mungan T. and Delibas N. (2007): Protective effects of vitamins $\mathrm{C}$ and $\mathrm{E}$ against endometrial Damage and Oxidative stress in fluoride Intoxication. Clin. Exp. Pharmacol. Physiol.; 34 (5-6): 467-474.

30. Matsuo S., Nakagawa H., Kiyomiya K. and Kurebe M. (2000): Fluoride-induced ultrastructural changes in exocrine pancreas cells of rats: fluoride disrupts the export of zymogens from the eough endoplasmic reticulum (rER). Arch. Toxicol.; 73:611-617.

31. Qujeq D., Laghaie B., Gholipour A., Solimani N. and Hassenzadeh S. (2002): Effects of sodiumfluoride on total serum protein levels and transaminaseactivity in rats. Biomed. Pharmacotherapy; 56(4):169-172.

32. Deng H., Kuang P., Cui H., Chen L., Luo Q., Fang J., Zuo Z., Deng J., Wang X., Zhao L. (2016): Sodium fluoride (NaF) induces the splenic apoptosis via endoplasmic reticulum (ER) stress pathway in viv and in vitro. Aging; 8(12):3552-3567.

33. Yang Y., Lin X., Huang H., Feng D., Ba Y., Cheng 
X. and Cui L. (2015): Sodium fluoride induces apoptosis and alters bcl-2 family protein expression in MC3T3-E1 osteoblastic cells. J. Environ. Sci.; 1(30):81-89.

34. Yang S., Wang Z., Farquharson C., Alkasir R., Zahra M., Ren G. and Han B. (2011): Sodium fluoride induces apoptosis through reactive oxygen species-mediated endoplasmic reticulum stress pathway in Sertoli cells. Biochem. Biophys. Res. Commun.; 410(4):910-915.

35. Chalubek D. (2003): Fluoride and oxidative stress. Fluoride; 36(4):217-228. 


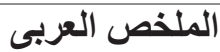

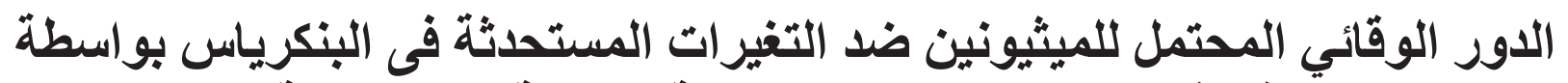

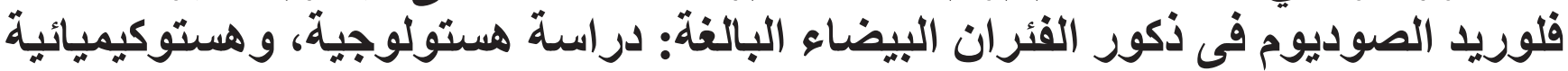
مناعية، وكمية البية

درية عبد الله محمد زغلول'، وائل محمد جاد الرب عسكر'، رينيه رفعت بشرى'، على أحمد أبوريا فرحات'

\section{قسم التثريح الآدمي وعلم الأجنة ـ كلية الطب - ' جامعة أسيوط - بجامعة الأزهر}

المقـــــمة:عندما تؤخذ مركبات الفلور ايد بكميات زائدة فإنها تحدث تغير ات نسيجية في كثير من الأعضاء. الميثيونين هو أحد مضادات الأكسدة الطبيعية. الغرض من البحث: تقييم التأثير ات الوقائية المحتملة للميثيونين علي البنكرياس في الفئران المعطاة فلوريد الصوديوم. المواد والطرق المستخدمة: تم استخدام عدد ثلاثثن من الفئر ان البيضاء الذكور البالغة و التي قسمت إلي ثلاث مجمو عات متساوية. المجموعة الأولى (المجموعة الضابطة): أعطيت 1 مل مياه مقطرة عن طريق الفم بواسطة أنبوب معدي يوميا لمدة خمسة وثثلاثون يوماً. المجموعة الثانية (مجموعة الفلوريد): أعطيت فلوريد الصوديوم بجر عة مقدارها 10 مليجر ام لكل كيلوجر ام من وزن الجسم عن طريق الفم بو اسطة أنبوب معدي يوميا لمدة خمسة وثناثون يوماً. المجمو عة الثالثة (مجموعة الفلوريد و الميثيونين): أعطيت فلوريد الصوديوم بنفس جر عة المجمو عة الثانية بالإضافة إلي تعاطي 2 مليجر ام ميثيو نين للفأر الو احد عن طريق الفم بو اسطة أنبوب معدي يوميا لمدة خمسة وثلاثون يوماً. ثم تمت التضحية بجميع مجمو عات الحيو انات بعد تخدير ها. تم إعداد عينات البنكرياس للفحص بالمجهرين الضوئي و الإلكتروني و الجسم المضاد للأنسولين و المضادة للإلتهاب المناعي. وكذلك تم حساب متوسط أعداد حبيبات الزيموجين و الخلايا الإيجابية للأنسولين لجميع مجمو عات الحيو انات. النتائج: لوحظ انخفاض معنوي في منوسط أعداد حبيبات الزيموجين و الخلايا الإيجابية للأنسولين في مجمو عة الفلوريد عند مقارنتها بالمجموعة الضابطة. وكثف الفحص النسيجي بالميكروسكوب الضوئي لعينات البنكرياس في مجموعة الفلوريد عن احتقان الأوعية الدموية في البنكرياس ، ارتشاح خلايا الدم في النسيج البيني ، واحتو اء عنيبات البنكرياس على فجوات ، وفقدان بنية الخلايا وتدهور ها. ومن خلال الفحص المجهري الإلكتروني ، أظهر البنكرياس اتساعًا في صهاريج الثبكية الإندوبلازمية ، وتدهور المينوكوندريا ، وكذللك لوحظ من خلال الأجسام المضادة المناعية والمضادة للأنسولين أن هناك تفاعلا إيجابياً ضعيفاً في مجموعة الفئر ان المعالجة بالفلوريد عند مقارنتها بالمجمو عة الضابطة. في حين أنه لوحظ تر اجع في التغير ات الكمية والنسيجية وكذللك تحسن تفاعلات الأنسولين المناعية في المجموعة الثالثة (مجمو عة فلوريد الصوديوم و الميثيونين) عند مقارنتها بالمجمو عة الثانية. الخلاصة: نستتتج من هذه الدر اسة أن تعاطي الميثيونين مع فلوريد الصوديوم يقلل من التغيير ات السمية في البنكرياس نتيجة زيادة تناول فلوريد الصوديوم. 